\title{
Effect of 1,4-dioxane on rabbit (Oryctolagus cuniculus ) reproductive hormonal level and histopathology of testes and ovaries
}

\author{
Muhammad Hashim*, Razia Iqbal, Sumera Afsheen, Atal Ul Mustafa
} Fahad, Usman Asghar, Maryum Daman and Mubeen Ghazanfar

Department of Zoology, University of Gujrat,Gujrat-Pakistan

*Corresponding author's email: hashimbiology@gmail.com

Citation

Muhammad Hashim, Razia Iqbal, SumeraAfsheen, Atal Ul Mustafa Fahad, Usman Asghar, Maryum Daman and Mubeen Ghazanfar. Effect of 1,4-dioxane on rabbit (Oryctolagus cuniculus ) reproductive hormonal level and histopathology of testes and ovaries. Pure and Applied Biology. Vol. 7, Issue 2, pp466-469.

http://dx.doi.org/10.19045/bspab.2018.70058

\begin{tabular}{llll}
\hline \hline Received: 13/12/2017 & Revised: 22/03/2018 & Accepted: 24/03/2018 & Online First: 06/04/2018 \\
\hline \hline
\end{tabular}

\section{Abstract}

In this study, 1,4-dioxane carcinogenicity and chronic toxicity on reproductive hormones was studied along with the histology(Sections) of testis and ovaries of rabbits (Oryctolagus cuniculus ). 1,4-dioxane 1000, 1500 and $2000 \mathrm{mg}$ per kilogram of body weight concentrations were given continuously to rabbits for period of 45 days. Increase in dose concentration lead to significant decrease in testosterone levels in males, and progesterone and estrogen levels in females. Histological alterations in testes and ovaries of rabbits were studied on $15^{\text {th }}, 30^{\text {th }}$ and $45^{\text {th }}$ days of treatment. No significant gonadal or hormonal change was observed on $15^{\text {th }}$ day. However, tissue damage, rupturing and necrosis in gonads and significant decrease in hormone level were observed after $30^{\text {th }}$ day $(\mathrm{p}<0.05)$. Damage as necrosis, cellular coagulation, tumors and hemorrhage was the most severe on $45^{\text {th }}$ day of study and Significant results were observed $(\mathrm{p}<0.05)$. This study concludes that 1,4-dioxane used in research work is histologically damaging to rabbit testes and ovaries and leads to reproductive complications. Therefore its use in various products should be discourage at commercial level.

Keywords: 1,4-dioxane; ELISA; Hemorrhage; Histopathology; IBM21; Necrosis; Rabbits;

Tissue damage; Tumors

\section{Introduction}

1,4-Dioxane is broadly used as a solvent in manufacturing of a large number of organic products like cosmetics, fertilizers and laboratory solvents. It is used as a stabilizer in chlorinated solvents as well as paint coatings [1]. 1,4-Dioxane have high affinity and solubility power for water [2]. According to [3] if 1,4-dioxane ingestion leads to accumulation in lungs, liver, testes, ovaries, stomach, kidneys, cardiac muscles , skeletal muscles and spleen. Its high concentration accrues damage to liver and kidneys.

According to [4] rats and mice show alterations in histological perspectives of reproductive organs (testes, ovaries, prostate, epididymis, seminal vesicle, uterus and vagina) when exposed to different concentrations of dioxane compound. Finding of [5] reported that 1,4dioxane causes histological alteration in male and female sex organs in rats. 
A study by [6] was carried out to test estrogenic effects of 1,4-dioxane in vitro and in vivo assays, it showed that 1,4dioxane has endocrine disruption properties, it is a little genotoxic and its effects on human reproductive system are unknown. This type of result was also confirmed by [7] showing that 1,4-dioxane is toxic for the normal production of hormones. The main mechanism of disruption or decrease in release of sex hormones includes interference with the synthesis, transport, metabolism and elimination of hormones, thereby decreasing the concentration of natural hormones [8].

This chemical has been reported to be found in many consumer products like PEG, Polyoxynol ethylene, Polyethylene glycol, Polyoxythylene Polyethylene and usually chemicals terminating with -eth and oxynol, in its original or in by-product form [9]. Mostly people exposed due to ingestion, inhalation or contact through skin and cause harmful effects in individuals having weak immune system and unable to detoxify these chemicals [10].

\section{Materials and methods}

Rabbits were procured from Veterinary Research Institute, Ghazi Road Lahore. And were kept in Zoology department animal house. And Chemical in pure form was purchased from Merck Pharmaceutical Industry Islamabad. Different concentrations were made and chemical was given by mixing in food twice a day for period of 45 days.

Histopathology is used to study testes and ovaries tissue damaged in rabbits. And
c) Cellular coagulation/Tumor sign

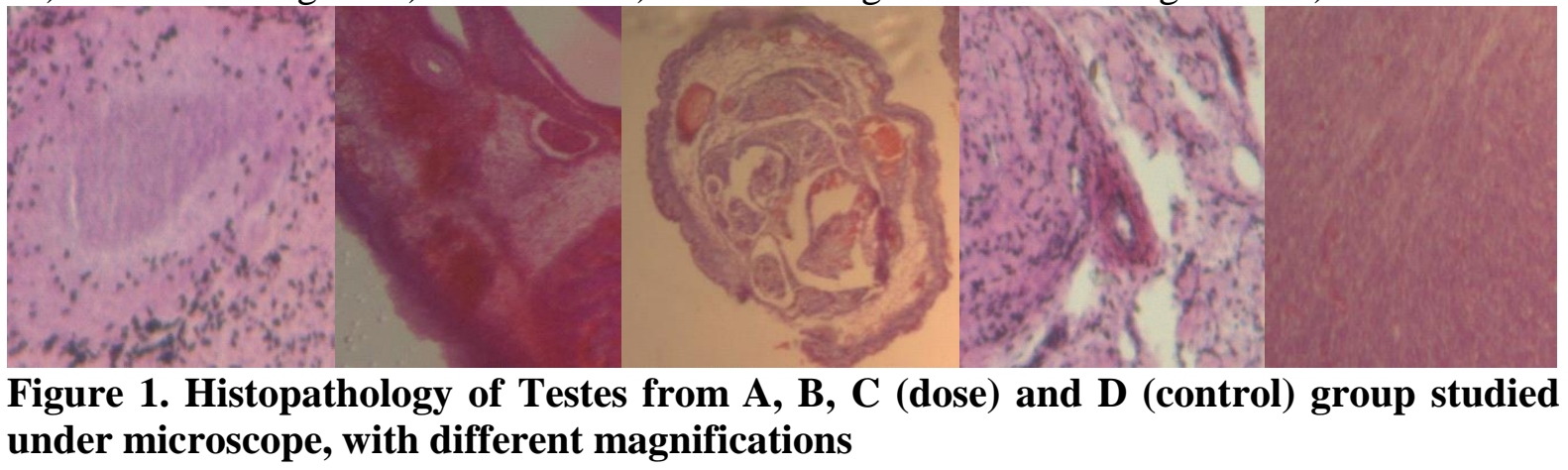
Figure 1. Histopathology of Testes from A, B, C (dose) and D (control) group studied under microscope, with different magnifications
a) Tissue damaged b) Necrosis
d) Normal

tissues were studied under stereo microscope with digital camera (attached with system model FRL $\mathrm{L}_{x} 400$ ) at different magnifications. For sex hormones testing quantitative ELISA was used and ELISA kit was Sex Hormones Binding Globulin (SHBG).Target hormones to study in male was testosterone and in females were estrogen and progesterone.

\section{Results and discussion}

Histopathology was done against different concentration of 1,4-dioxane in groups with control group D after $15^{\text {th }}, 30^{\text {th }}$ and $45^{\text {th }}$ day of dose treatments of all the groups. A was treated with $1000 \mathrm{mg} / \mathrm{kg}$,B was treated with 1500 and $\mathrm{C}$ with 2000. As a result tumors, necrosis, hemorrhage, tissue damaged and lesions were seen in testes (Figure 1) and ovaries (Figure 2) of rabbits. According to [4] rats and mice show alterations in histological perspectives of reproductive organs (testes, ovaries, prostate, epididymis, seminal vesicle, uterus and vagina) when exposed to different concentrations of dioxane compound.

Hormonal changes result are also confirmed [7] testosterone level in male (Table 1), progesterone level in pregnant female rabbits (Table 2) and progesterone and Estradiol level in non-pregnant female rabbits (Table $3 \& 4$ ) this revelled that 1,4dioxane disturb reproductive hormone production. This chemical was described as genotoxic and causing the suppression of release of hormonal secretion in mice. This result was also reported by [11]. Statically calculated results are here as given and Pvalue shows significant values. 

a) Necrosis
b) Tumor formation
c) Hemorrhage
d) Normal

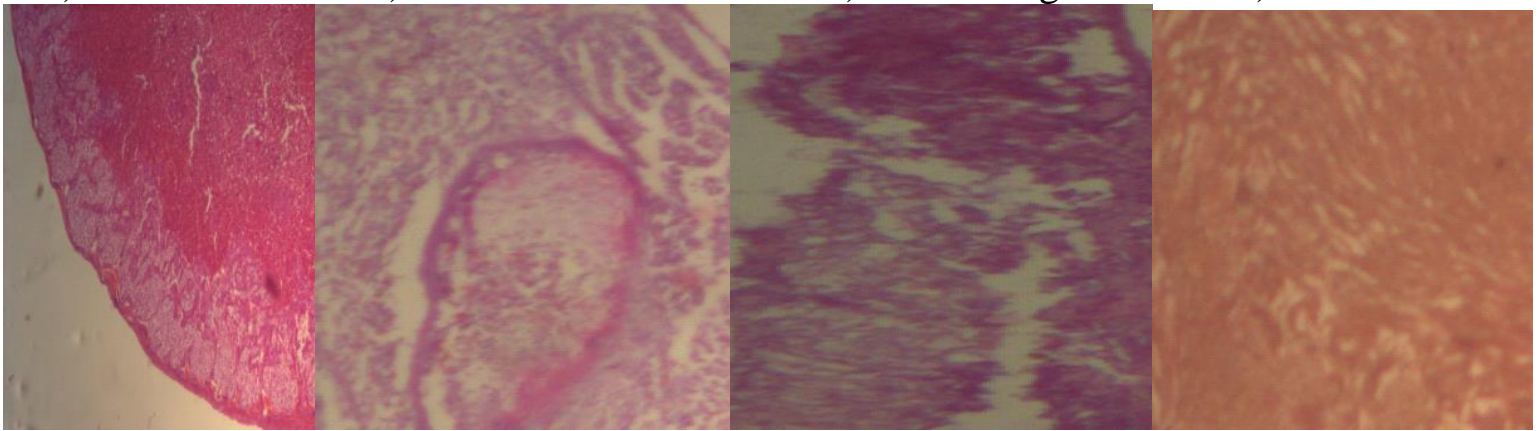

Figure 2. Histopathology of Ovaries from A, B, C (dose) and D (control) group studied under microscope, with different magnifications

Table 1. Effect of 1,4-dioxane on testosterone level in male rabbit

\begin{tabular}{|c|c|c|c|c|}
\hline Days of Dose & Control & $\begin{array}{c}\text { Group A } \\
(\mathbf{1 0 0 0} \mathbf{m g} / \mathbf{K g})\end{array}$ & $\begin{array}{c}\text { Group B } \\
(\mathbf{1 5 0 0 m g} / \mathbf{K g})\end{array}$ & $\begin{array}{c}\text { Group } \\
\mathbf{C}(\mathbf{2 0 0 0 m g} / \mathbf{K g})\end{array}$ \\
\hline $\mathbf{1 0}$ & $7.22 \pm 0.21$ & $7.90 \pm 0.02$ & $7.46 \pm 0.12$ & $6.32 \pm 0.19$ \\
\hline $\mathbf{2 0}$ & $6.32 \pm 2.13$ & $4.07 \pm 0.59$ & $5.30 \pm 0.18$ & $4.03 \pm 0.19^{*}$ \\
\hline $\mathbf{3 0}$ & $8.14 \pm 0.05$ & $4.13 \pm 2.44^{*}$ & $2.04 \pm 0.58^{* *}$ & $2.30 \pm 0.19^{* *}$ \\
\hline
\end{tabular}

Table 2. Effects of 1,4-dioxane progesterone level (ng/ml) in pregnant female rabbits

\begin{tabular}{|c|c|c|c|c|}
\hline Trimester & Control & $\mathbf{1 0 0 0}$ & $\mathbf{1 5 0 0}$ & $\mathbf{2 0 0 0}$ \\
\hline First Trimester & $24 \pm 2.35$ & $20 \pm 1.20$ & $17 \pm 1.09$ & $14 \pm 1.20^{*}$ \\
\hline Mid Trimester & $43 \pm 1.10$ & $30 \pm 2.5^{*}$ & $27 \pm 0.34^{*}$ & $223 \pm 4.0^{* *}$ \\
\hline $\begin{array}{c}\text { Third } \\
\text { Trimester }\end{array}$ & $122 \pm 3.0$ & $78.24 \pm 2.08^{* *}$ & $76.20 \pm 2.40^{* *}$ & $61 \pm 1.71^{* * *}$ \\
\hline
\end{tabular}

Table 3. Effects of 1, 4-dioxane on progesterone level $(\mathrm{ng} / \mathrm{ml})$ in non-pregnant female rabbits

\begin{tabular}{|c|c|c|c|c|}
\hline Phases & Control & $\mathbf{1 0 0 0}$ & $\mathbf{1 5 0 0}$ & $\mathbf{2 0 0 0}$ \\
\hline Folicular & $1.01 \pm 0.23$ & $0.92 \pm 0.15$ & $0.57 \pm 0.18^{*}$ & $0.49 \pm 0.21^{*}$ \\
\hline Luteal & $12.52 \pm 0.16$ & $7.19 \pm 0.58$ & $4.51 \pm 0.13^{*}$ & $2.27 \pm 2.18^{* *}$ \\
\hline
\end{tabular}

Table 4. Effects of 1,4-dioxane on Estradiol level (pg/ml) in non-pregnant female rabbits

\begin{tabular}{|c|c|c|c|c|}
\hline Phases & Control & $\mathbf{1 0 0 0}$ & $\mathbf{1 5 0 0}$ & $\mathbf{2 0 0 0}$ \\
\hline Folicular & $123 \pm 3.45$ & $91 \pm 2.07$ & $85 \pm 1.12^{*}$ & $61.07 \pm 2.15^{* *}$ \\
\hline Luteal & $133 \pm 2.15$ & $108 \pm 1.04^{*}$ & $91.05 \pm 1.23^{*}$ & $72 \pm 2.10^{* *}$ \\
\hline
\end{tabular}

Asterisks shows significant difference against controls; $* *=\mathrm{P}<0.001, \mathrm{P}<0.01$ and $*=\mathrm{P}<0.05$

\section{Conclusions}

The study shows that 1,4-dioxane is histologically damaging and causes serious problems when enters the body. Overall decrease in hormonal level is seen when compared to control group after $20^{\text {th }}$ and $30^{\text {th }}$ days for all concentrations of $1,4-$ dioxane. Gonadal damage was observed after $30^{\text {th }}$ day and $45^{\text {th }}$ day for all concentrations. However, the level of damage observed was directly proportional to the concentration of 1,4-dioxane used showing necrosis, cellular coagulation, hemorrhage, tumors and rupturing.Use of 1,4-dioxane should be discouraged in daily used commercial products like shampoos , solvent, lotions, fertilizers and cosmetic products. Further studies should be encouraged to determine the toxic level of 1,4-dioxane by increasing animal sample for study 


\section{Authors' contributions}

Conceived and designed the experiments: M Hashim \& RIqbal, Performed the experiments: M Hashim, AUM Fahad \& U Asghar, Analyzed the data: AUM Fahad, Contributed materials/ analysis/ tools: S Afsheen, Wrote the paper: M Daman \& M Ghazanfar.

\section{Acknowledgment}

I would like to extend my gratitude to the many people who helped to bring this research project to fruition. First, I would like to indebted to my supervisor Dr. Razia Iqbal, Associate Professor, Department of Zoology, Dr. Nadia Zeeshan Assistant Professor, Department of Biochemistry and Molecular Biology, University of Gujrat, Gujrat, for their involvement in the discussion for this research project without their passionate participation and input; this research work could not have been successfully completed.

\section{References}

1. Lewis RJ (1993). Hawley's condensed chemical dictionary, 12th ed., New York: Van Nostrand Reinhold pp 426.

2. Nannelli A, De-rubertis A, longo V \& Gervasi PG (2005). Effects of dioxane on cytochrome P450 enzymes in liver, kidney, lung and nasal mucosa of rat. Arch Toxicol 79(2): 74-82.

3. Agency of Toxic Substance and Disease Registry (2012). Toxicological Profile for 1, 4 -dioxane,4770 Buford Hwy NE, Atlanta, GA 30341 ,http://www.atsdr.cdc.gov/ToxProfiles /tp187.pdf
4. Kano et al (2008). Thirteen-week oral toxicity of 1,4-dioxane in rats and mice. J Toxicology Sci 33: 141-153.

5. Kasai $\mathrm{T}$, Kano $\mathrm{H}$, Umeda $\mathrm{Y}$ et al (2009). Two-year inhalation study of carcinogenicity and chronic toxicit. State Water Resources Control Board, 2009, California.

6. Nishihara, T, Nishikawa JI, Kanayama $\mathrm{T}$ et al (2000). Estrogenic activities of 517 chemicals by yeast two-hybrid assay. J Health Sci 46: 282-298.

7. Duncan B, Vavricka E, and Morrison R. (2004). A forensic overview of 1,4Dioxane. Environ Claims J 16(1): 6979.

8. Mnif W, Pillon A, Balaguer P, Bartegi A (2011). Endocrine xenoestrogenics disrupters, molecular mechanisms and detection methods. Therapies 62: 369386.

9. Gasser RF, Cork RJ, Stillwell BJ \& McWilliams DT (2014). Rebirth of human embryology. Developmental Dynamics 243(5): 621-628.

10. Asghar U, Malik MF, Javed A (2016). Pesticide Exposure and Human Health: A Review. J Ecosys Ecograph S5: 005. doi: 10.4172/2157-7625.S5-005

11. Wilbur et al (2012). Biodegradation of Tetrahydrofuran and 1,4-Dioxane by Soluble Diiron Monooxygenase in Pseudonocardia sp. Strain ENV478 J Mol Microbiol Biotechnol 22: 312316. 